\title{
NIERÓWNOŚCI W POZIOMIE ROZWOJU SPOLECZNO-GOSPODARCZEGO GMIN WIEJSKICH WOJEWÓDZTWA ŁÓDZKIEGO
}

\begin{abstract}
Zarys treści: Zasadniczym celem artykułu jest wyjaśnienie nierówności w poziomie rozwoju społeczno-gospodarczego gmin wiejskich województwa łódzkiego oraz porównanie ich do wyników badań sprzed wejścia Polski do Unii Europejskiej. Rezultatem przeprowadzonego postępowania badawczego jest klasyfikacja gmin wiejskich regionu łódzkiego według poziomu rozwoju społeczno-gospodarczego. Źródłem danych statystycznych był Bank Danych Lokalnych, Głównego Urzędu Statystycznego. Ranking gmin opracowano dla 2008 i 2013 roku, czyli dla początku i końca okresu programowania rozwoju w Unii Europejskiej. Badania mają charakter dynamiczny, dzięki czemu możliwe było zaprezentowanie zmian w nierównościach rozwoju społeczno-gospodarczego.

Wyniki badań pokazały, że nastąpiło zmniejszenie się ogólnych nierówności rozwojowych na terenach wiejskich województwa. Pomiędzy przyjętymi w badaniu latami (2008-2013) doszło do wzrostu poziomu rozwoju społeczno-gospodarczego. W największym zakresie wzrost poziomu rozwojowego zaobserwowano w gminach wiejskich położonych poza aglomeracją łódzką, bardzo często w terenach peryferyjnych, w obszarach o przewadze funkcji rolniczych. Ważnym elementem wzrostu społeczno-ekonomicznego były większe wydatki inwestycyjne, wzrost ogólnych wydatków gminy, i wynikające częściowo z tego uzupełnianie podstawowych niedoborów infrastrukturalnych (wzrost warunków życia). Za największy problem rozwojowy gmin wiejskich należy uznać pogarszającą się sytuację demograficzną. $Z$ pewnością ważnym czynnikiem dalszych przemian społeczno-ekonomicznych będzie zmniejszający się udział dzieci i młodzieży oraz osób w wieku produkcyjnym mobilnym.
\end{abstract}

Słowa kluczowe: gminy wiejskie, rozwój społeczno-gospodarczy, nierówności, województwo łódzkie.

\section{Wprowadzenie}

Jednym z istotnych celów geografii jako nauki jest wyjaśnienie zróżnicowania środowiska geograficznego. Charakter wyjaśnienia w dużej mierze zależy od przyjętego paradygmatu. W geografii społeczno-ekonomicznej największą 
popularnością cieszy się paradygmat przestrzenny (Lisowski 2005). Jego główną cechą jest wyjaśnienie struktur i procesów społeczno-ekonomicznych w wymiarze przestrzennym na różnych poziomach organizacji terytorialnej. F. Braudel (1971) uważał, że geografia buduje swą odrębność czyniąc centralnym punktem swych rozważań relację społeczeństw do przestrzeni, tj. jest specyficznym studium człowieka i jego działalności poprzez przestrzeń. Geografia człowieka wyjaśnia struktury i procesy społeczne $\mathrm{w}$ ich przestrzennym wymiarze (terytorialnym), w warstwie wyjaśniającej koncentrując się na procesie wytwarzania różnych form środowiska życia ludzi (krajobrazów, regionów, miejsc - miast i wsi) i relacjach, które łączą człowieka z otoczeniem (Wójcik, Suliborski 2014).

Istotną rolę w takim ujęciu przypisuje się próbie wyjaśnienia zróżnicowania przestrzennego, przy czym i w tym przypadku można wyróżnić wiele podejść, zależnie od przyjętej orientacji teoretyczno-metodologicznej (por. Wójcik, Suliborski 2014). Na szeroko pojęte zróżnicowanie tej przestrzeni składają się nierówności i dysproporcje (Tobiasz-Lis 2014). Nierówności są naturalną cechą przestrzeni, ale także efektem rozwoju społeczno-gospodarczego. Gdy nierówności między elementami przestrzeni, bądź jej cechami, nie spełniają warunków ładu społecznego i gospodarczego, możemy wówczas mówić o dysproporcjach w środowisku życia ludzi. Panujący ład społeczny stanowi pewną umowę, która określa, jaki układ wartości uznajemy za obowiązujący w naszej kulturze. Nierówność, jako kategoria społeczno-ekonomiczna, zawiera w sobie trzy ujęcia problemu, tj. nierówny dostęp, nierówny podział dóbr oraz niesprawiedliwość społeczną. Należy uznać, iż nie każda nierówność jest dysproporcją, stając się nią tylko wówczas, gdy jest tak postrzegana społecznie, natomiast każda dysproporcja stanowi pewną formę nierówności (por. Tobiasz-Lis 2014). Pojęcie nierówności związane jest $\mathrm{z}$ autotelicznym sposobem pojmowania przestrzeni, tzn. traktuje się ją jako zbiór odseparowanych elementów i powiązań między nimi przyjmujących charakter substancjalnych (por. Lisowski 2005, s. 34-35). Dysproporcje natomiast są sposobem opisu przestrzeni wyrastającym z ujęcia heterotelicznego, gdzie przypisuje się ją do określonych podmiotów. W niniejszym opracowaniu przyjęto autoteliczne ujęcie przestrzeni, a jej zróżnicowanie opisano w kategoriach nierówności.

Na rozwój nierówności w przestrzeni może mieć wpływ wiele czynników. Do najważniejszych zalicza się potencjał zasobów środowiska przyrodniczego i społeczno-gospodarczego. W obrębie zasobów środowiska społeczno-gospodarczego istotną rolę odgrywa struktura funkcjonalno-przestrzenna oraz charakter sieci osadniczej. Oprócz czynników o charakterze strukturalnym istotne znaczenie mają uwarunkowania genetyczne, czyli pewna ścieżka rozwoju społecznego i wynikające z niej materialne i duchowe dziedzictwo kulturowe (stan zagospodarowania, kapitał społeczny, regionalizmy). 


\section{Nierówności w poziomie rozwoju społeczno-gospodarczego obszarów wiejskich województwa lódzkiego w świetle dotychczasowych badań}

Nierówności w poziomie rozwoju społeczno-gospodarczego obszarów wiejskich stanowią część ogólnych nierówności tego typu w regionie łódzkim (por. np. Jewtuchowicz, Suliborski 2002, 2006). W ostatnim czasie większą uwagę w tym zakresie poświęcono obszarom zurbanizowanym, tj. Łodzi (Suliborski, Wójcik 2014) oraz obszarowi metropolitalnemu (Jewtuchowicz, Wójcik 2010; Suliborski, Przygodzki 2010). Zróżnicowanie przestrzenne poziomu rozwoju społeczno-gospodarczego wsi było przedstawiane rzadziej, choć w ostatnich 10 latach wykonano w tym zakresie kilka interesujących prób. Problem nierówności rozwojowych w obszarach wiejskich był poruszany w dwóch podstawowych kontekstach, tj.:

1) funkcje osiedli wiejskich i urbanizacja wsi;

2) społeczno-gospodarczy i kulturowy aspekt przemian wsi.

Dominującym współcześnie sposobem badań wielofunkcyjności wsi jest wzorzec metodyczny wypracowany na przełomie lat 80. i 90. XX wieku (Stola 1993). Na jego podstawie dokonano ponownego rozpoznania struktury funkcjonalno-przestrzennej obszarów wiejskich Polski po pierwszym okresie transformacji gospodarczej wsi (Bański, Stola 2002; Czapiewski 2010). W przypadku regionu łódzkiego nie podejmowano $\mathrm{w}$ tym zakresie pogłębionych badań, koncentrując się raczej na zróżnicowaniu poziomu rozwoju społeczno-gospodarczego gmin wiejskich w oparciu o szerokie zestawy wskaźników (por. Wójcik 2006, 2008c). Podstawowy wniosek z tych badań odnosił się do stwierdzenia stosunkowo dużych nierówności w poziomie rozwoju pomiędzy centrum i peryferiami regionu. Zwrócono uwagę, że najlepiej rozwinięte gminy wiejskie koncentrują się w bezpośrednim sąsiedztwie miast i dużych ośrodków przemysłowych. Najwyższym potencjałem społeczno-ekonomicznym charakteryzowały się wówczas obszary wiejskie aglomeracji łódzkiej, obszaru bełchatowskiego oraz tereny sąsiadujące $\mathrm{z}$ dużymi miastami powiatowymi, które wytwarzają własne strefy podmiejskie. W wyjaśnieniu tych nierówności istotną rolę odgrywa czynnik genetyczny. W procesie formowania się regionu łódzkiego szybki awans Łodzi i jej aglomeracji do rangi dużych krajowych skupisk miejsko-przemysłowych doprowadził do wykształcenia się regionu funkcjonalnego, którego centrum (ŁAM) góruje potencjałem społecznym i ekonomicznym nad obszarami peryferyjnymi (Wójcik 2006). Podobne wnioski towarzyszyły ocenie nierówności $\mathrm{w}$ zakresie zróżnicowania poziomu rozwoju wielofunkcyjnego obszarów wiejskich województwa łódzkiego (Wójcik 2008b, 2010a, 2013a). ${ }^{1}$

${ }^{1}$ Badania te obejmowały również tereny wiejskie gmin miejsko-wiejskich, co wpłynęło na identyfikację znacznych różnic w poziomie rozwoju obszarów wiejskich. Różnice pomiędzy gminami wiejskimi, zwłaszcza na terenach peryferyjnych, były stosunkowo niewielkie. 
Intensywność przekształceń strefy podmiejskiej Łodzi była przyczyną podjęcia pogłębionych badań nad nierównościami społecznymi i gospodarczymi jako konsekwencji zróżnicowania procesu dyfuzji funkcji miejskich. Jedną z prac podejmujących wyzwania oceny zróżnicowania procesów osadniczych jest praca M. Wójcika (2008a) na temat przemian społecznych i gospodarczych wsi aglomeracji łódzkiej w nowych warunkach ustrojowych. Celem pracy było m.in. określenie kierunków, tempa i typów odpowiednich procesów oraz wskazania ich uwarunkowań strukturalnych i społecznych. Wykazano, że na działania człowieka wpływa stan rozwoju i typ systemu osadniczego. Natomiast poziom rozwoju systemu osadniczego jest odbiciem rozmaitych ról ludzi (społecznych i gospodarczych) działających $\mathrm{w}$ ramach tego systemu. Zauważono, że we wsiach graniczących $\mathrm{z}$ dużym miastem aktywność społeczna prowadzi do przekształceń, które na poziomie strukturalnym przejawiają się w rozwoju funkcji odpowiednich obszarów (od prostych do złożonych). W zewnętrznej strefie aglomeracji, w której działania ludzkie skierowane są na przeczekanie, przetrwanie, dochodzi do stagnacji funkcjonalnej tych obszarów (Wójcik 2008a). W ostatnim czasie badania zostały pogłębione o aspekty społeczne i kulturowe. Skoncentrowano się na analizie zachowań i percepcji przestrzeni wsi przez zasiedziałych oraz nowych mieszkańców wsi. Próbowano również określić zmiany jakie powstają $\mathrm{w}$ lokalnych społecznościach pod wpływem inwestycji realizowanych z funduszy UE (Wójcik 2010b, 2013b). Wyniki badań wskazują na rosnącą atomizację społeczną, wzajemną nieufność grup ludzkich do siebie oraz zderzenie oczekiwań (poszukiwanie ideału zamieszkiwania) z realiami wsi urbanizujących, przede wszystkim braku satysfakcji z sąsiedztwa (Wójcik 2013c).

\section{Cele i zakres badań}

Zasadniczym celem artykułu jest wyjaśnienie nierówności w poziomie rozwoju społeczno-gospodarczego gmin wiejskich województwa łódzkiego oraz porównanie ich do wyników badań sprzed wejścia Polski do Unii Europejskiej (Wójcik 2006, 2008c). Rezultatem przeprowadzonego postępowania badawczego jest klasyfikacja gmin wiejskich regionu łódzkiego według poziomu rozwoju społeczno-gospodarczego.

Źródłem danych statystycznych był Bank Danych Lokalnych Głównego Urzędu Statystycznego. Ranking gmin opracowano dla 2008 i 2013 roku, czyli dla początku i końca okresu programowania rozwoju w Unii Europejskiej. Badania mają charakter dynamiczny, dzięki czemu możliwe było zaprezentowanie zmian w nierównościach rozwoju społeczno-gospodarczego.

Podstawową strukturę administracyjną województwa łódzkiego tworzy 177 gmin, w tym 133 gminy wiejskie (75\% ogółu), które stanowią obszar badań. Gminy wiejskie zajmują ponad 13,5 tys. $\mathrm{km}^{2}$, czyli $74,5 \%$ powierzchni woje- 
wództwa. Zarówno największa, jak i najmniejsza obszarowo gmina wiejska są położone w aglomeracji łódzkiej (Zgierz - $199 \mathrm{~km}^{2}$ i Ksawerów - 14 km²). Liczba ludności zamieszkująca gminy wiejskie to 735 tys. osób, co stanowi niecałe 30\% mieszkańców regionu łódzkiego. W 2013 roku największa liczba ludności zamieszkiwała w gminie Andrespol, w aglomeracji łódzkiej (13 180 osób), natomiast najmniej liczna pod tym względem była gmina Regnów, w powiecie rawskim (1 846 osób) ${ }^{2}$.

\section{Metodologia badań}

Do określenia poziomu rozwoju społeczno-gospodarczego gmin wiejskich województwa łódzkiego wykorzystano metodę miernika rozwoju Z. Hellwiga. Jest to jedna $\mathrm{z}$ metod taksonomicznych. Efektem tej metody jest miara agregatowa, która obliczana jest za pomocą syntetycznego wskaźnika odległości badanego obiektu od teoretycznego wzorca rozwoju (Hellwig 1968). Metoda ta jest często wykorzystywana w badaniach zróżnicowania poziomu rozwoju (por. np. Stec 2008; Łogwiniuk 2011). W analizie nierówności rozwoju gmin wiejskich regionu łódzkiego teoretyczny wzorzec rozwoju stanowi hipotetyczna gmina o najlepszych wartościach zmiennych.

Początkowo przyjęto 25 wskaźników ujętych w 5 grupach. W pierwszej fazie analizy statystycznej odrzucono zmienne o najniższym współczynniku zmienności. Za wartość krytyczną przyjęto $\mathrm{V}=0,10$. Spośród 25 zmiennych tylko dwie odznaczały się niską zmiennością, a były to: wskaźnik feminizacji oraz przeciętna powierzchnia użytkowa mieszkania na 1 osobę. Kolejnym etapem było stworzenie tablicy korelacyjnej przy użyciu wskaźnika korelacji liniowej Pearsona. Badanie siły związku między cechami wyeliminowało 6 zmiennych. Do ostatecznej oceny poziomu rozwoju społeczno-gospodarczego gmin wiejskich uwzględniono zbiór 17 zmiennych, tzn.:

1. zmienne demograficzne, $t \mathrm{j}$.:

- przyrost naturalny w przeliczeniu na 1000 mieszkańców,

- zameldowania w przeliczeniu na 1000 mieszkańców,

- saldo migracji zagranicznych w przeliczeniu na 1000 mieszkańców;

2. zmienne aktywności ekonomicznej ludności, tj.:

- ludność w wieku przedprodukcyjnym i poprodukcyjnym w odniesieniu do liczby ludności w wieku produkcyjnym,

- liczba pracujących na 100 osób w wieku produkcyjnym,

- udział osób bezrobotnych w liczbie ludności ogółem,

- podmioty wpisane do rejestru REGON w przeliczeniu na 10 tys. mieszkańców;

\footnotetext{
${ }^{2}$ Bank Danych Lokalnych GUS, stat.gov.pl.
} 


\section{3. zmienne zagospodarowania przestrzennego, $\mathrm{tj}$.:}

- liczba osób przypadająca na 1 izbę,

- liczba osób korzystających z oczyszczalni ścieków w stosunku do liczby ludności ogółem,

- udział użytków rolnych w powierzchni gminy ogółem;

4. zmienne infrastruktury spolecznej, t $\mathrm{j}$.:

- czytelnicy bibliotek w przeliczeniu na 1000 mieszkańców,

- liczba udzielonych noclegów w przeliczeniu na 1000 mieszkańców,

- liczba przychodni zdrowia w przeliczeniu na 10 tys. mieszkańców;

5. zmienne sytuacji finansowej, $\mathrm{t} j$.:

- wydatki gminy w przeliczeniu na 1 mieszkańca,

- udział dotacji inwestycyjnych w dochodach gminy ogółem,

- roczne wpływy z opłaty targowej na targowiskach stałych i sezonowych ogółem w dochodach gminy ogółem,

- udział wydatków na drogi publiczne w wydatkach gminy ogółem.

Wyżej wymienione 17 cech w kolejnej fazie analizy statystycznej objętych zostało procedurą normalizacji poprzez standaryzację, co pozwoliło zbudować macierz wartości cech. Posłużyła ona do wyznaczenia wzorca rozwoju - gminy teoretycznej, opisanego maksymalnymi wartościami standaryzowanymi (stymulanty) lub wartościami minimalnymi (destymulanty). Następnie porównano standaryzowane wartości cech opisujące badane gminy z wartościami dla wzorca, określając stopień ich podobieństwa (różnica). Ostatni etap badań polegał na obliczeniu wskaźnika syntetycznego dla każdej gminy wiejskiej. Im wartość tego wskaźnika była bardziej zbliżona do ogólnego wzorca, tym poziom jej rozwoju był wyższy.

Klasyfikacja gmin ze względu na poziom rozwoju wymagała posłużenia się parametrami miernika taksonomicznego, jakimi są średnia arytmetyczna oraz odchylenie standardowe. Wyróżniono następujące grupy gmin:

- grupa I - o najwyższym poziomie rozwoju - do grupy tej należą gminy, których odległość od wzorca przekracza wartość sumy średniej i odchylenia;

- grupa II - o średnim poziomie rozwoju, odległość od wzorca zawiera się w przedziale między sumą a różnicą średniej i odchylenia;

- grupa III - o najniższym poziomie rozwoju, odległość od wzorca nie przekracza wartości różnicy średniej i odchylenia.

Taki podział zbiorowości ma na celu przede wszystkim wyróżnienie gmin o najwyższych i najniższych wartościach wskaźnika syntetycznego, co pozwoliło wskazać kierunek i tempo zmian $\mathrm{w}$ zakresie nierówności $\mathrm{w}$ poziomie rozwoju społeczno-gospodarczego gmin wiejskich. 


\section{Klasyfikacja gmin wiejskich regionu lódzkiego}

W 2008 roku do grupy o najwyższym poziomie rozwoju zaliczono 18 gmin, czyli 14\% ogólnej liczby takich jednostek (rys. 1). W 2013 roku grupa ta była dużo mniejsza i jej liczebność wynosiła 9 gmin (rys. 2). Podobną sytuację odnotowano $\mathrm{w}$ przypadku grupy o najniższym poziomie rozwoju. Liczba gmin zmniejszyła się z 20 (2008) do 6 (2013). W konsekwencji wzrosła liczebność grupy o średnim poziomie rozwoju społeczno-gospodarczego. W 2013 roku liczyła ona 118 jednostek terytorialnych, podczas gdy w 2008 roku było to 95 gmin wiejskich. Rozstęp (różnica pomiędzy najlepszą i najsłabszą gminą) w 2008 roku wynosił 7,5 pkt. ${ }^{3}$ W 2013 roku rozstęp pomiędzy gminą Łanięta (najniższa wartość wskaźnika) a gminą Kleszczów wynosił 12,7 pkt. Wzrost tej różnicy wynika przede wszystkim z umacniającej się bardzo szybko pozycji najbogatszej gminy w Polsce - Kleszczowa.

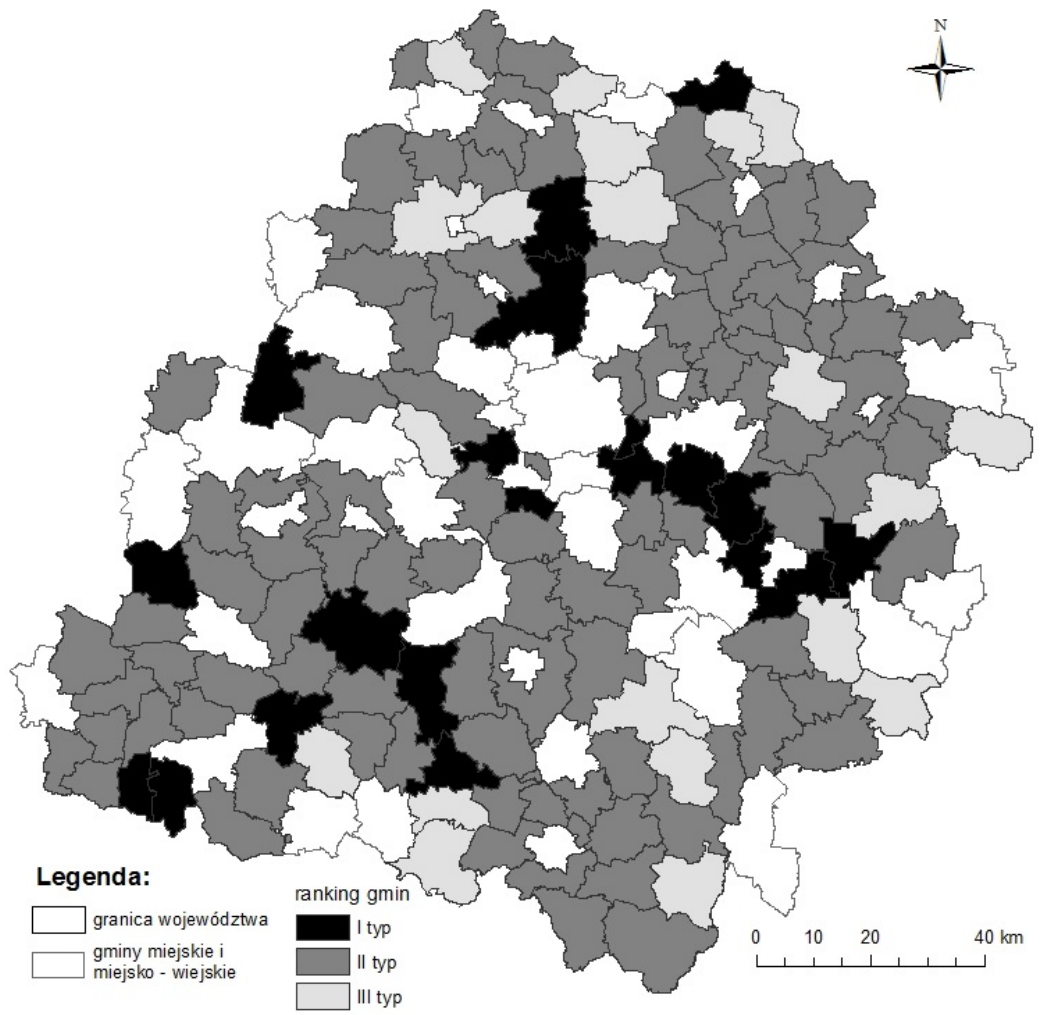

Rys. 1. Klasyfikacja gmin wiejskich w województwie łódzkim w 2008 roku Źródło: opracowanie własne na podstawie danych GUS

\footnotetext{
${ }^{3}$ Najwyższy wskaźnik rozwoju - Inowłódz, najniższy - Nowa Brzeźnica.
} 


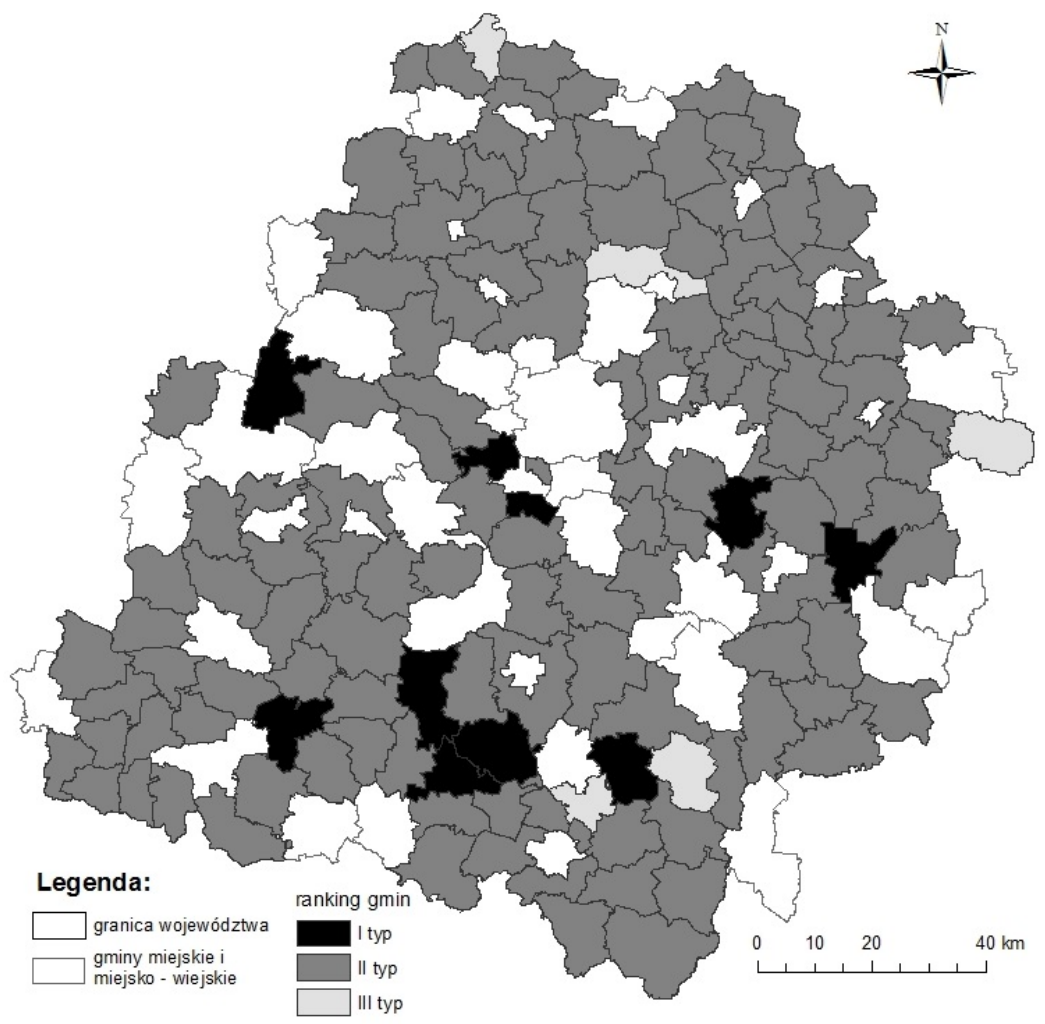

Rys. 2. Klasyfikacja gmin wiejskich w województwie łódzkim w 2013 roku Źródło: opracowanie własne na podstawie danych GUS

Należy mieć na uwadze, że wyniki badań mają względny charakter, co wynika z przyjętej metody (odległość od wzorca). Zachowane dla obu przyjętych lat jednakowe warunki, tj. zmienne diagnostyczne (cechy) oraz podział zbiorowości według tych samych reguł pozwalają na stwierdzenie prawidłowości rozwojowych gmin wiejskich województwa łódzkiego. Wyniki badań dla obu przyjętych lat (2008 i 2013) przedstawiają relację statystyczną pomiędzy wartościami zmiennych dla gminy i wyznaczonymi dla nich wartościami wzorcowymi oraz relację pomiędzy przyjętymi cechami diagnostycznymi w formie wskaźnika syntetycznego. Niezależnie od ogólnej zmiany średniego poziomu rozwoju gmin wiejskich w regionie, metoda ta określa relacje statystyczne pomiędzy przyjętymi obiektami badań (gminami) w zakresie zmiennych diagnostycznych oraz różnice, które wystąpiły w okresie 2008-2012.

Interpretacja wyników badań pozwala stwierdzić zmniejszenie nierówności opisanych przede wszystkim liczebnością grup o najwyższych i najniższych wskaźnikach rozwoju. Z przeprowadzonych wcześniej przez M. Wójcika (2006, 2008c) badań wynikało, że różnice w poziomie rozwoju samych gmin wiejskich 
nie są duże i generalnie na tle kraju są to jednostki o relatywnie niskim poziomie rozwojowym (por. Rosner, Stanny 2014). Jedynie niewielką cześć zbiorowości można było zaklasyfikować do grupy o najwyższym poziomie rozwoju, co wyjaśniono głównie funkcją zurbanizowania, czyli w dużej mierze wielkością sektora pozarolniczych działalności ekonomicznych, napływem ludności i procesami inwestycyjnymi (głównie tereny wiejskie gmin miejsko-wiejskich oraz gminy wiejskie aglomeracji łódzkiej oraz obszaru bełchatowskiego).

Rezultaty badań potwierdzają to spostrzeżenie, zwłaszcza dla roku 2008, kiedy poziom nierówności był wyższy i sytuację tę można było również zinterpretować wpływem procesów urbanizacji, co decydowało o wyróżniającej się pozycji gmin wiejskich położonych w aglomeracji łódzkiej, wokół niektórych większych ośrodków miejskich, wzdłuż pasm osadniczych (np. Łódź - Tomaszów Maz.) oraz w pobliżu dużych inwestycji przemysłowych (obszar bełchatowski). Gminy charakteryzujące się najniższym poziomem rozwoju w większości położone były w peryferyjnych obszarach regionu łódzkiego, a ich główną funkcją była działalność rolnicza.

Zmniejszenie się nierówności rozwojowych pomiędzy rokiem 2008 i 2013, względne obniżenie poziomu rozwoju dużej części gmin o najlepszych wynikach w 2008 roku i wzrost poziomu części gmin najsłabszych jest wynikiem procesów, które część badaczy nazywa „spóźnioną” transformacją wsi (por. Fedyszak-Radziejowska 2010). Wyniki analizy zmian wartości miernika syntetycznego (2008-2013) ukazały bowiem jego wzrost we wszystkich gminach wiejskich regionu łódzkiego (rys. 3). Najliczniejszą grupę stanowiły jednostki o średnim wzroście wskaźnika syntetycznego rozwoju (58 jednostek, tj. 44\% gmin wiejskich). Wzrostem wysokim i niskim charakteryzowało się po $37 \mathrm{gmin}$ wiejskich. Interesujący jest układ przestrzenny, w którym trudno dopatrzyć się istotnych prawidłowości. Najważniejszym wnioskiem jest wzrost poziomu rozwoju w gminach poza obszarem aglomeracji łódzkiej. Największy obszar koncentracji takich gmin znajduje się w powiatach o przeważających funkcjach rolniczych, tj. okolice Łęczycy, Łowicza, Skierniewic oraz Piotrkowa Tryb. Bardzo duży wzrost odnotowała uprzemysłowiona gmina Kleszczów - najbogatsza gmina w Polsce utrzymująca się głównie z podatków płaconych przez Kopalnię Węgla Brunatnego i Elektrownię „Bełchatów”.

Choć $\mathrm{w}$ ostatnich latach za jedno $\mathrm{z}$ najczęstszych uwarunkowań wyjaśniających przemiany społeczno-gospodarcze wsi uznaje się wpływ środków z funduszy europejskich (zwłaszcza RPO i PROW), to zestaw czynników jest bardziej złożony, zwłaszcza w zakresie przemian demograficznych, społecznych oraz funkcjonalnych, których widoczne efekty pojawiły się po około 15-20 latach od początku przemian transformacyjnych w Polsce przełomu lat 80. i 90. XX wieku. Przykład zmniejszenia się nierówności rozwojowych obszarów wiejskich województwa łódzkiego wynika $\mathrm{w}$ dużej mierze $\mathrm{z}$ uwarunkowań strukturalnych, tj. zwiększenia dynamiki (często jej zapoczątkowania) procesów ekonomicznych $\mathrm{w}$ jednostkach o relatywnie niskich wskaźnikach poziomu 
rozwoju gospodarczego (najczęściej dominujące tradycyjne funkcje rolnicze) przy jednoczesnych przemianach społecznych związanych z różnymi składowymi kapitału społecznego oraz ludzkiego (por. np. Psyk-Piotrowska, Zajda 2013). Podstawowe tendencje dla gmin wiejskich województwa łódzkiego są widoczne w zakresie zmiany średniej arytmetycznej przyjętych cech diagnostycznych oraz współczynnikach zmienności (iloraz odchylenia standardowego i średniej arytmetycznej) (por. tab. 1).

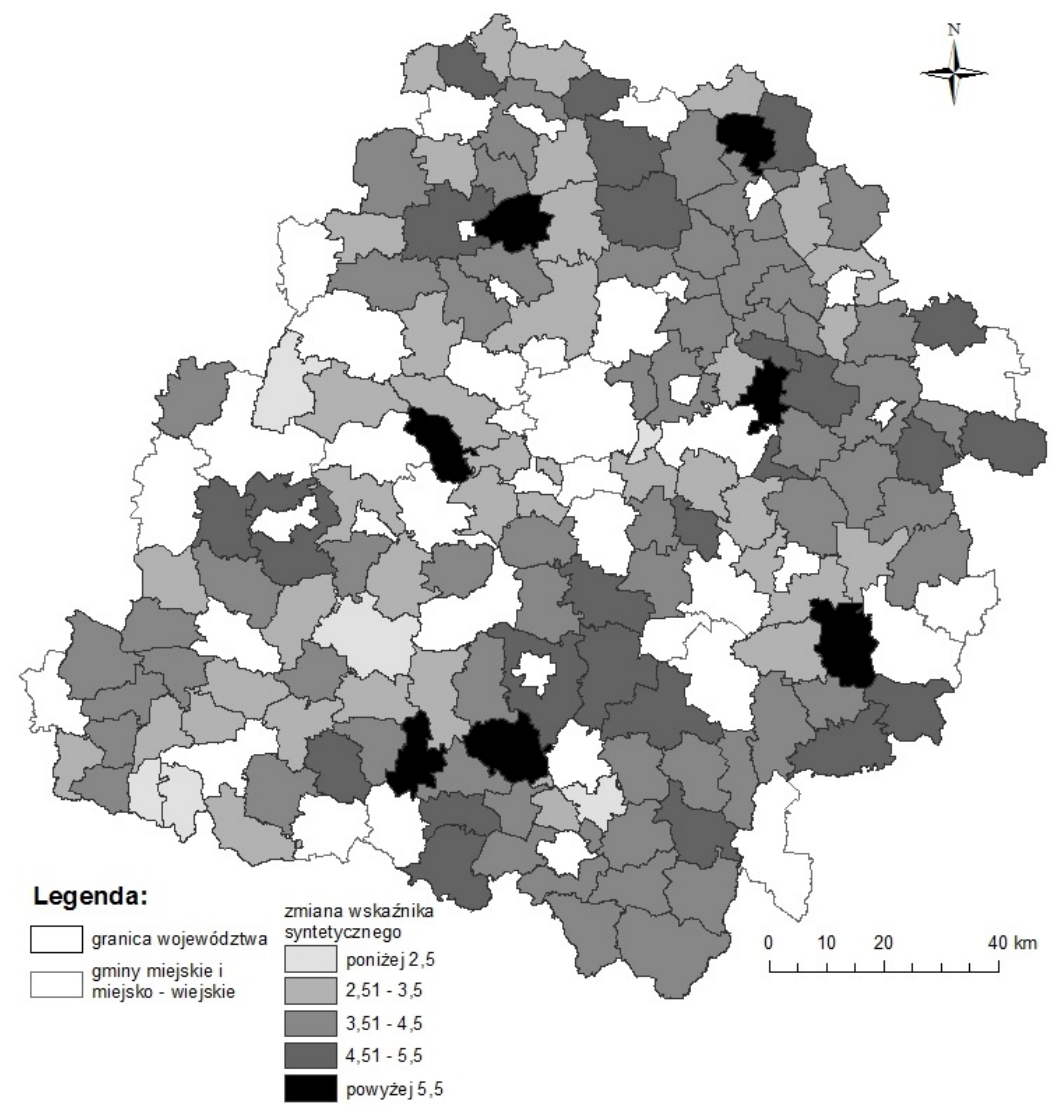

Rys. 3. Dynamika zmian poziomu rozwoju społeczno-gospodarczego Źródło: opracowanie własne na podstawie danych GUS 
Tabela 1

Klasa wskaźnika zmienności w 2008 i 2013 roku dla wyselekcjonowanych cech w gminach wiejskich województwa łódzkiego ${ }^{4}$

\begin{tabular}{|c|c|c|c|}
\hline Zmienna & $\begin{array}{c}\text { Klasa } \\
\text { wskaźnika } \\
\text { zmienności } \\
(2008)\end{array}$ & $\begin{array}{c}\text { Klasa } \\
\text { wskaźnika } \\
\text { zmienności } \\
(2013)\end{array}$ & $\begin{array}{l}\text { Wzrost / } \\
\text { spadek } \\
\text { wskaźnika } \\
\text { zmienności }\end{array}$ \\
\hline 1 & 2 & 3 & 4 \\
\hline $\begin{array}{l}\text { 1. Przyrost naturalny w przeliczeniu } \\
\text { na } 1000 \text { mieszkańców }\end{array}$ & $\begin{array}{l}\text { skrajnie duża } \\
\text { zmienność }\end{array}$ & $\begin{array}{l}\text { bardzo duża } \\
\text { zmienność }\end{array}$ & spadek \\
\hline $\begin{array}{l}\text { 2. Zameldowania w przeliczeniu } \\
\text { na } 1000 \text { mieszkańców }\end{array}$ & $\begin{array}{c}\text { duża } \\
\text { zmienność }\end{array}$ & $\begin{array}{c}\text { duża } \\
\text { zmienność }\end{array}$ & wzrost \\
\hline $\begin{array}{l}\text { 3. Saldo migracji zagranicznych } \\
\text { w przeliczeniu na } 1000 \text { mieszkań- } \\
\text { ców }\end{array}$ & $\begin{array}{l}\text { skrajnie duża } \\
\text { zmienność }\end{array}$ & $\begin{array}{l}\text { skrajnie duża } \\
\text { zmienność }\end{array}$ & spadek \\
\hline $\begin{array}{l}\text { 4. Ludność w wieku przedprodukcyj- } \\
\text { nym i poprodukcyjnym w odnie- } \\
\text { sieniu do liczby ludności w wieku } \\
\text { produkcyjnym }\end{array}$ & $\begin{array}{c}\text { mała } \\
\text { zmienność }\end{array}$ & $\begin{array}{l}\text { mała } \\
\text { zmienność }\end{array}$ & spadek \\
\hline $\begin{array}{l}\text { 5. Liczba pracujących na } 100 \text { osób } \\
\text { w wieku produkcyjnym }\end{array}$ & $\begin{array}{l}\text { skrajnie duża } \\
\text { zmienność }\end{array}$ & $\begin{array}{l}\text { skrajnie duża } \\
\text { zmienność }\end{array}$ & spadek \\
\hline $\begin{array}{l}\text { 6. Udział osób bezrobotnych } \\
\text { w liczbie ludności ogółem }\end{array}$ & $\begin{array}{l}\text { przeciętna } \\
\text { zmienność }\end{array}$ & $\begin{array}{l}\text { przeciętna } \\
\text { zmienność }\end{array}$ & spadek \\
\hline $\begin{array}{l}\text { 7. Podmioty wpisane do rejestru } \\
\text { REGON w przeliczeniu na } \\
10 \text { tys. mieszkańców }\end{array}$ & $\begin{array}{l}\text { przeciętna } \\
\text { zmienność }\end{array}$ & $\begin{array}{l}\text { przeciętna } \\
\text { zmienność }\end{array}$ & spadek \\
\hline $\begin{array}{l}\text { 8. Liczba osób przypadająca na } \\
1 \text { izbę }\end{array}$ & $\begin{array}{c}\text { mała } \\
\text { zmienność }\end{array}$ & $\begin{array}{c}\text { mała } \\
\text { zmienność }\end{array}$ & wzrost \\
\hline $\begin{array}{l}\text { 9. Liczba osób korzystających } \\
\text { z oczyszczalni ścieków w stosunku } \\
\text { do liczby ludności ogółem }\end{array}$ & $\begin{array}{l}\text { bardzo duża } \\
\text { zmienność }\end{array}$ & $\begin{array}{l}\text { bardzo duża } \\
\text { zmienność }\end{array}$ & spadek \\
\hline $\begin{array}{l}\text { 10. Udział użytków rolnych } \\
\text { w powierzchni gminy ogółem }\end{array}$ & $\begin{array}{c}\text { mała } \\
\text { zmienność }\end{array}$ & $\begin{array}{c}\text { mała } \\
\text { zmienność }\end{array}$ & spadek \\
\hline $\begin{array}{l}\text { 11. Czytelnicy bibliotek w przelicze- } \\
\text { niu na } 1000 \text { mieszkańców }\end{array}$ & $\begin{array}{c}\text { duża } \\
\text { zmienność }\end{array}$ & $\begin{array}{c}\text { duża } \\
\text { zmienność }\end{array}$ & wzrost \\
\hline $\begin{array}{l}\text { 12. Liczba udzielonych noclegów } \\
\text { w przeliczeniu na } 1000 \text { miesz- } \\
\text { kańców }\end{array}$ & $\begin{array}{l}\text { skrajnie duża } \\
\text { zmienność }\end{array}$ & $\begin{array}{l}\text { skrajnie duża } \\
\text { zmienność }\end{array}$ & spadek \\
\hline $\begin{array}{l}\text { 13. Liczba przychodni zdrowia w prze- } \\
\text { liczeniu na } 10 \text { tys. mieszkańców }\end{array}$ & $\begin{array}{c}\text { duża } \\
\text { zmienność }\end{array}$ & $\begin{array}{c}\text { duża } \\
\text { zmienność }\end{array}$ & spadek \\
\hline $\begin{array}{l}\text { 14. Wydatki gminy w przeliczeniu na } \\
1 \text { mieszkańca }\end{array}$ & $\begin{array}{l}\text { bardzo duża } \\
\text { zmienność }\end{array}$ & $\begin{array}{l}\text { bardzo duża } \\
\text { zmienność }\end{array}$ & spadek \\
\hline
\end{tabular}

\footnotetext{
${ }^{4}$ Objaśnienia metodyczne pod tabelą.
} 
Tabela 1 (cd.)

\begin{tabular}{|c|c|c|c|}
\hline 1 & 2 & 3 & 4 \\
\hline $\begin{array}{c}\text { 15. Udział dotacji inwestycyjnych } \\
\text { w dochodach gminy ogółem }\end{array}$ & $\begin{array}{c}\text { bardzo duża } \\
\text { zmienność }\end{array}$ & $\begin{array}{c}\text { bardzo duża } \\
\text { zmienność }\end{array}$ & wzrost \\
\hline $\begin{array}{c}\text { 16. Roczne wpływy z opłaty targowej } \\
\text { na targowiskach stałych i sezono- } \\
\text { wych ogółem w dochodach } \\
\text { gminy ogółem }\end{array}$ & $\begin{array}{c}\text { skrajnie duża } \\
\text { zmienność }\end{array}$ & $\begin{array}{c}\text { skrajnie duża } \\
\text { zmienność }\end{array}$ & spadek \\
\hline $\begin{array}{l}\text { 17. Udział wydatków na drogi pu- } \\
\text { bliczne w wydatkach gminy } \\
\text { ogółem }\end{array}$ & $\begin{array}{c}\text { duża } \\
\text { zmienność }\end{array}$ & $\begin{array}{c}\text { duża } \\
\text { zmienność }\end{array}$ & spadek \\
\hline
\end{tabular}

Objaśnienia:

$-\mathrm{V}<20 \%$ - mała zmienność

$-20 \%<\mathrm{V}<40 \%$ - przeciętna zmienność

$-40 \%<\mathrm{V}<100 \%$ - duża zmienność

$-100 \%<\mathrm{V}<150 \%$ - bardzo duża zmienność

- V > 150\% - skrajnie duża zmienność

Źródło: opracowanie własne.

Stosunkowo dużą zmianą jest ogólny spadek wartości współczynnika przyrostu naturalnego $\mathrm{w}$ gminach wiejskich. O ile w 2008 roku wynosił on około $-1,9$ osoby na 1000 mieszkańców, to w 2013 roku zmalał on do poziomu -3 osoby na 1000 mieszkańców. W przypadku 2008 i 2013 roku wskaźniki zmienności były wysokie, choć doszło do zmiany klasy wskaźnika ze skrajnie dużej do bardzo dużej. Oznacza to, że w ostatnich latach gminy wiejskie w województwie zaczęły się w coraz większym stopniu upodabniać pod tym względem do obszarów zurbanizowanych, w których obniżające się wskaźniki przyrostu naturalnego ukazują narastające problemy demograficzne, w tym prognozowaną dla regionu stosunkowo dużą depopulację w najbliższych 20 latach, tym bardziej, że migracje nie uzupełniają najczęściej strat w ruchu naturalnym. Wskaźnikiem, który można uznać za prognostyczny względem narastających $\mathrm{w}$ następnych latach problemów demograficznych jest ujemne saldo migracji zagranicznych na stałe (rejestrowanych).

Wśród zmiennych aktywności ekonomicznej ludności najbardziej czytelną zmianą pomiędzy wziętymi pod uwagę latami jest wzrost średniego poziomu bezrobocia. W 2013 roku udział osób zarejestrowanych jako bezrobotni w stosunku do liczby mieszkańców wynosił około 5\%, podczas gdy w 2008 roku było to około $3,8 \%$. Co ciekawe w tym samym czasie nastąpił wzrost liczby firm zarejestrowanych w systemie REGON w przeliczeniu na 10 tys. mieszkańców z poziomu $591 \mathrm{w} 2008$ roku do $623 \mathrm{w} 2013$. Obydwie zmienne cechowały się jednocześnie niskimi wskaźnikami zmienności.

Za miarę postępu cywilizacyjnego na wsi można uznać zmiany w zakresie obsługi ludności przez składowe infrastruktury technicznej i społecznej. W badanym okresie znacząco wzrósł udział osób w ogóle mieszkańców gminy, 
którzy korzystają ze zbiorowego systemu kanalizacji z 12,5\% do 20,5\%, choć wskaźnik zmienności nadal jest bardzo wysoki. Poprawiła się również sytuacja $\mathrm{w}$ formalnym dostępie do przychodni lekarskich na terenach wiejskich.

Wśród wszystkich przyjętych $\mathrm{w}$ badaniu zmiennych największe znaczenie dla rozwoju ekonomicznego, wzrostu warunków życia oraz dla zagospodarowania przestrzennego ma wzrost wydatków gminy. W 2008 roku średnio w gminach wiejskich regionu wydatki wynosiły 2,7 tys. zł na 1 osobę, podczas gdy w 2013 roku było to 3,4 tys. zł. W pewnym stopniu przyczyniły się do tego wzmożone inwestycje w infrastrukturę techniczną i społeczną gmin. Średni udział środków na inwestycje w budżecie gmin wzrósł z 3,7\% do 4,5\%. Jednocześnie te cechy finansowe miały bardzo wysokie wskaźniki zmienności, co dowodzi dużych różnic pomiędzy gminami zwłaszcza w zakresie możliwości inwestycyjnych.

\section{Podsumowanie}

Podsumowując można stwierdzić, że nastąpiło zmniejszenie się ogólnych nierówności rozwojowych na terenach wiejskich województwa. Pomiędzy przyjętymi w badaniu latami (2008-2013) doszło do wzrostu poziomu rozwoju społeczno-gospodarczego. W największym zakresie wzrost poziomu rozwojowego zaobserwowano $\mathrm{w}$ gminach wiejskich położonych poza aglomeracją łódzką, bardzo często $\mathrm{w}$ terenach peryferyjnych, w obszarach o przewadze funkcji rolniczych. Ważnym elementem wzrostu społeczno-ekonomicznego były większe wydatki inwestycyjne, wzrost ogólnych wydatków gminy i wynikające częściowo $\mathrm{z}$ tego uzupełnianie podstawowych niedoborów infrastrukturalnych (wzrost warunków życia). Liderem zmian w województwie i jednocześnie w skali kraju jest gmina Kleszczów, której obecne zagospodarowanie przestrzenne, struktury demograficzne, warunki życia wynikają z wieloletniego oddziaływania bardzo dobrej sytuacji finansowej. Za największy problem rozwojowy gmin wiejskich należy uznać pogarszającą się sytuację demograficzną $\mathrm{Z}$ pewnością ważnym czynnikiem dalszych przemian społeczno-ekonomicznych będzie zmniejszający się udział dzieci i młodzieży oraz osób w wieku produkcyjnym mobilnym. Możliwości inwestycyjne wywołane w dużej mierze przez programy pomocowe UE dały okazję do przetestowania sprawności samorządów lokalnych, od których w dużej mierze będzie zależał dalszy wzrost oparty na tym czynniku (por. Wójcik 2013d). Ograniczenie strumienia środków na inwestycje w perspektywie po 2020 roku będzie sprawdzianem dla gmin z umiejętności planowania strategicznego oraz pokaże czy wyrównanie nierówności miało charakter pozorny czy trwały. Interesujące w tym kontekście jest również określenie czy proces zmniejszania nierówności dotyczy również mikroskali przestrzennej, czyli wewnątrz gmin wiejskich. 


\section{LITERATURA}

Bański J., Stola W., 2002, Przemiany struktury przestrzennej i funkcjonalnej obszarów wiejskich $w$ Polsce, „Studia Obszarów Wiejskich”, 3, Zespół Badań Transformacji Obszarów Wiejskich Instytutu Geografii i Przestrzennego Zagospodarowania PAN, Komisja Obszarów Wiejskich PTG, Warszawa.

Braudel F., 1971, Historia i trwanie, Czytelnik, Warszawa.

Czapiewski K., 2010, Koncepcja wiejskich obszarów sukcesu społeczno-gospodarczego i ich rozpoznanie $w$ województwie mazowieckim, „Studia Obszarów Wiejskich”, 22, Zespół Badań Obszarów Wiejskich Instytutu Geografii i Przestrzennego Zagospodarowania PAN, Komisja Obszarów Wiejskich PTG, Warszawa.

Fedyszak-Radziejowska B., 2010, Społeczności wiejskie pięć lat po akcesji do UE sukces spóźnionej transformacji, [w:] Wilkin J., Nurzyńska I. (red.), Polska wieś 2010. Raport o stanie wsi, Wydawnictwo Naukowe Scholar, Warszawa.

Hellwig Z., 1968, Zastosowanie metody taksonomicznej do typologicznego podziału krajów ze względu na poziom ich rozwoju oraz zasoby i strukturę wykwalifikowanych $k a d r$, „Przegląd Statystyczny”, 15(4), PWN, Warszawa, s. 307-326.

Jewtuchowicz A., Suliborski A. (red.), 2002, Struktury i procesy kształtujące łódzki region społeczno-gospodarczy, ZERiOŚ, UŁ, Fundacja Inkubator, Łódź.

Jewtuchowicz A., Suliborski A. (red.), 2006, Przestrzenne zróżnicowanie procesów transformacji społeczno-gospodarczej w regionie łódzkim, Wydawnictwo UŁ, Łódź.

Jewtuchowicz A., Wójcik M. (red.), 2010, Łódzka Metropolia. Problemy integracji gospodarczej, Wydawnictwo Biblioteka, Łódź.

Lisowski A., 2005, Geografia jako nauka chorologiczna, [w:] Maik W., Rembowska K., Suliborski A. (red.), Geografia jako nauka o przestrzeni, środowisku i krajobrazie. Podstawowe idee i koncepcje w geografii, t. 1, Wydawnictwo Uniwersytetu Łódzkiego, Łódź, s. 25-49.

Łogwiniuk K., 2011, Zastosowanie metod taksonomicznych $w$ analizie porównawczej dostępu do infrastruktury ICT przez młodzież szkolna w Polsce, ,Economy and Management", 1, s. 7-23.

Psyk-Piotrowska E., Zajda K. (red.), 2013, Podejście Leader i inne formy aktywizacji społeczności wiejskich, „Acta Universitatis Lodziensis”, Folia Sociologica, 44.

Rosner A., Stanny M., 2014, Monitoring rozwoju obszarów wiejskich. Etap I, FEFRWP, IRWiR, Warszawa.

Stec M., 2008, Ranking poziomu rozwoju krajów Unii Europejskiej, „Gospodarka Narodowa", 7-8, s. 99-118.

Stola W., 1993, Struktura przestrzenna i klasyfikacja funkcjonalna obszarów wiejskich Polski, „Dokumentacja Geograficzna”, 3, Instytut Geografii i Przestrzennego Zagospodarowania PAN, Warszawa.

Suliborski A., Przygodzki Z. (red.), 2010, Łódzka Metropolia. Problemy integracji społecznej i przestrzennej, Wydawnictwo Biblioteka, Łódź.

Suliborski A., Wójcik M. (red.), 2014, Dysproporcje społeczne i gospodarcze $w$ przestrzeni Łodzi. Czynniki, mechanizmy, skutki, Wydawnictwo Uniwersytetu Łódzkiego, Łódź. 
Tobiasz-Lis P., 2014, Dysproporcje w przestrzeni miejskiej. Ujęcie teoretyczne, [w:] Suliborski A., Wójcik M. (red.), Dysproporcje społeczne i gospodarcze w przestrzeni Łodzi. Czynniki, mechanizmy, skutki, Wydawnictwo Uniwersytetu Łódzkiego, Łódź, s. $49-61$.

Wójcik M., 2006, Główne uwarunkowania rozwoju społeczno-gospodarczego obszarów wiejskich województwa tódzkiego, [w:] Głębocki B., Kacprzak E. (red.), Przemiany struktury przestrzennej rolnictwa - sukcesy i niepowodzenia, Bogucki Wydawnictwo Naukowe, Poznań, s. 163-176.

Wójcik M., 2008a, Przemiany społeczno-gospodarcze wsi aglomeracji łódzkiej w okresie transformacji ustrojowej, Wydawnictwo Uniwersytetu Łódzkiego, Łódź.

Wójcik M., 2008b, Pozarolnicze funkcje obszarów wiejskich aglomeracji łódzkiej, [w:] Gierańczyk W., Kluba M. (red.), Problemy i metody oceny kontinuum miejsko-wiejskiego w Polsce, ,Studia Obszarów Wiejskich”, 13, Zespół Badań Obszarów Wiejskich Instytutu Geografii i Przestrzennego Zagospodarowania PAN, Komisja Obszarów Wiejskich PTG, Warszawa, s. 125-137.

Wójcik M., 2008c, Identyfikacja terenów suburbanizacji w strukturze przestrzennej obszarów wiejskich regionu łódzkiego, „Studia Komitetu Przestrzennego Zagospodarowania Kraju PAN", 69, s. 140-149.

Wójcik M., 2010a, Zmiany funkcji obszarów wiejskich $w$ województwie łódzkim w ujęciu koncepcji bazy ekonomicznej (1999-2007), [w:] Wójcik M. (red.), Studia nad baza ekonomiczna miast i rynkiem pracy w województwie tódzkim, Karpacki Instytut Rozwoju Regionalnego w Nowym Sączu, Zakład Geografii Regionalnej i Społecznej Uniwersytetu Łódzkiego, Nowy Sącz-Łódź, s. 57-69.

Wójcik M., 2010b, Struktura i działanie - geograficzno-społeczna interpretacja oddziatywania funduszy Unii Europejskiej na przykładzie programu ,Odnowa wsi”, [w:] Kacprzak E., Kołodziejczak A. (red.), Rola środków Unii Europejskiej w rozwoju obszarów wiejskich, „Studia Obszarów Wiejskich”, 24, Zespół Badań Obszarów Wiejskich Instytutu Geografii i Przestrzennego Zagospodarowania PAN, Komisja Obszarów Wiejskich PTG, Warszawa, s. 186-201.

Wójcik M., 2013a, Non-agricultural economic functions of rural areas in the Eódzkie Voivodeship (1999-2009), „Barometr Regionalny”, 11(2), s. 43-50.

Wójcik M., 2013b, Territorial identity of countryside residents in the suburban areas of Łódź, Poland, „Quaestiones Geographicae”, 32(2), s. 69-79.

Wójcik M., 2013c, Przemiany społeczno-przestrzenne osiedli wiejskich. Studium przypadku Łódzkiego Obszaru Metropolitalnego, Wydawnictwo Uniwersytetu Łódzkiego, Łódź.

Wójcik M., 2013d, Wieś 2050 - refleksje na temat przyszłości wsi polskiej ze szczególnym uwzględnieniem regionu łódzkiego, [w:] Bański R. (red.), Polska wieś w perspektywie dtugookresowej - ujęcie regionalne, „Studia Obszarów Wiejskich”, 31, s. 39-52.

Wójcik M., Suliborski A., 2014, Geografia społeczna w Polsce - geneza, koncepcje i zróżnicowanie problemowe, ze szczególnym uwzględnieniem studiów geograficzno-miejskich w ośrodku łódzkim, [w:] Suliborski A., Wójcik M. (red.), Dysproporcje społeczne i gospodarcze $w$ przestrzenie Łodzi. Czynniki, mechanizmy, skutki, Wydawnictwo Uniwersytetu Łódzkiego, Łódź, s. 17-48. 


\title{
INEQUALITIES IN SOCIO-ECONOMIC DEVELOPMENT IN RURAL COMMUNES OF THE ŁÓDŹ REGION
}

\begin{abstract}
The main aim of this article is to explain disparities in socio-economic development of rural communes in the Łódź region and to compare them to the results of studies conducted before Poland joined the European Union. The research resulted in the classification of rural communes in the Łódź region according to their level of socio-economic development. Statistical data were taken from the Local Data Bank, Central Statistical Office. The ranking of communes was compiled for 2008 and 2013, i.e. for the beginning and end of the development programming period in the European Union. Studies are dynamic, making it possible to present the changes in socio-economic development disparities.

The results have shown that general development inequalities in rural areas of the region have decreased. In the time period chosen for the study (2008-2013), there was an increase in the level of socio-economic development. The greatest increase in development level was noticed in rural communes located outside of the Łódź agglomeration, very often in the peripheral areas with dominant agricultural function. Some important elements of the socio-economic growth were increased investment expenses, higher overall expenses and, partially resulting from them, supplementation of basic infrastructural shortcomings (improved living conditions). The worsening demographic situation should be considered the greatest development problem for rural communes. It is obvious that further socio-economic transformations will be impacted by the decreasing share of children and youths, as well as mobile working age population.
\end{abstract}

Key words: rural municipalities, social and economic development, inequalities, Łódź region.

Dr hab. Marcin Wójcik, prof. UŁ Mgr Justyna Tomczyk Katedra Geografii Regionalnej i Społecznej Wydział Nauk Geograficznych Uniwersytet Łódzki 